
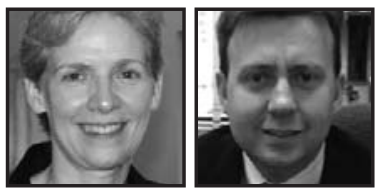

\title{
Tools for Inquiry: Improving Questioning in the Classroom
}

\author{
Marcia. A. B. Delcourt, Western Connecticut State University \\ Jason McKinnon, Ridgefield Public Schools
}

\section{ABSTRACT}

The ability to ask questions is the foundation of inquiry learning. While national research standards promote the use of inquiry skills such as questioning, many programs for pre-service teachers do not include training in the development of these skills, leaving teachers and children lacking in this area. A four-step plan is described for assessing inquiry skills by monitoring types of questions employed in the classroom and implementing changes in classroom practices. Results not only reveal that teachers and their students learn to ask more questions, but also that the number of higher order thinking questions actually increases using these methods.

nquiry is fundamentally about asking questions and being curious. Inquiry means to discover, show interest, be motivated, problem-find, problem-solve, think, and create meaning. "The idea of producing knowledge that is meaningful to yourself and others, and using knowledge to accomplish purposes that include those you set yourself or that you believe in, is central to inquiry" (Aulls \& Shore, 2007, p. 23). If a purpose of education is to assist students to become independent learners and thinkers, then inquiry deserves a place in every classroom, beginning with how to formulate a question.

We take for granted that people know how to ask a question. It is assumed that if a child uses the word "why" then he or she has learned how to ask an appropriate question. While this behavior may be developmentally accurate for a two-yearold, once children enter school they do not necessarily learn about "nuances" in 
questioning because inquiry is not typically stressed in teacher preparation programs (Zembal-Saul, Blumenfeld, \& Krajcik, 2000), and many teachers have difficulties employing inquiry-based instruction (Oliveira, 2010, p. 422).

While organizations such as the National Research Council (NRC) promote the use of questioning skills (NRC, 2000), most teachers do not provide their students with direct training in question asking until a student is given instruction in scientific thinking through conducting a science experiment, or taking a research-related course such as statistics or psychology. In fact, when the key words "inquiry in education" were used to review available databases in education for peer-reviewed sources published from 2000 to 2011, the search revealed a total of 62, 43, and 46 references pertaining to the elementary, middle, and secondary school levels, respectively. Between $74 \%$ and $93 \%$ of these references related to the field of science. Few other subject areas were specifically named in the titles, key terms, or abstracts. (For research about inquiry instruction across content areas, refer to Aulls \& Shore, 2007; Shore, Aulls, \& Delcourt, 2007). Although reports of using inquiry in schools occur predominantly in science classrooms, science educators maintain that there is "little evidence" that inquiry-based instruction is being used in these classes (Hermann \& Miranda, 2010, p. 27), despite numerous models available in the literature (Harris \& Burke, 2008; Hendrickson, 2006; Jansen, 2011).

Not only do many students lack the training to formulate questions, but they also often have low self-confidence when presenting their ideas, problems, or projects (Shore, Aulls, \& Delcourt, 2007). Because they worry about what others will think of them, students become reluctant, uncomfortable, or even fearful about asking questions (Oliveira, 2010; Starko, 2007). At some point, these students may have felt that their questions were not supported due to inappropriate feedback (Salon, 2008). Another deterrent to asking questions is a lack of instructional time (Ramsey, Gabbard, Clawson, Lee, \& Henson, 1990). There can be so many demands on a teacher to include a specified amount of content in a limited amount of time that he or she uses most of a classroom period to check for basic understanding, thereby consciously or unconsciously reducing the number of higher order thinking skills questions that require lengthier, more in-depth responses.

If the numbers and types of questions being asked by teachers and students in a classroom are not given a high priority, most questions are asked by the teacher, and a majority of these can be classified at the knowledge/comprehension (K/C) level of thinking (Delcourt \& Carkner, 1996). It should be no surprise that if teachers are asking all or most of the questions, then students do not have the opportunity to ask 
them. Furthermore, if teachers ask questions that only require basic knowledge, such as "Who was the antagonist in this story?" or"What are the ingredients needed for this experiment?," then many students will not have practice responding to or formulating questions, especially those representing complex levels of thinking.

\section{How Can Questioning in the Classroom Be Improved?}

\section{An Example of Improving Questioning Skills}

The first way to improve questioning is to assess what is happening. The second step is to develop a plan for improvement. Thirdly, the situation should be reassessed. Finally, new targets should be set. The following guidelines were developed for a course project in Learning, Cognition, and Teaching as part of an EdD in the Instructional Leadership program at Western Connecticut State University in Danbury, CT.

Purpose. The purpose of this activity is to influence student learning by improving the use of Higher Order Thinking (HOT) questions in a school environment. Ideally, both students and teachers should be using HOT skills on a regular basis through both questions and statements made during the school day. This activity provides data about the numbers and types of questions being used, as well as strategies to improve HOT questions in the classroom.

Directions. One way to monitor improvement is to take a baseline, develop a plan for change, and assess the results. In order to record HOT skills, data need to be gathered about the types of questions and comments being made in a classroom. The Classroom Practices Record (CPR) (Westberg, Archambault, Dobyns, \& Salvin, 1993 ) is an instrument that can be used to analyze activities during a class session. While the CPR was originally used by researchers for the National Research Center on the Gifted and Talented to target participation of specific children in classroom activities, it can also be used to observe selected students or an entire class. The observer records the types of activities such as whole group, individual seat-work, small group, learning center, etcetera. The classroom conversations are then scripted and coded. It is also a good idea to record wait time, the amount of time between asking a question and soliciting a response. Refer to the report by Westberg et al. for complete directions for using the CPR. 
An educator can reflect on his or her own teaching using an audio or video taping system or being observed by a colleague. Using either technique, conversations can be scripted directly onto the CPR.

\section{Procedures.}

1. Step One: Assess Numbers and Types of Questions Using the Classroom Practices Record

a. Become familiar with the CPR. Review the self-test at the end of the manual.

b. Record 1-3 or more baseline observations of teaching. Strategies could include monitoring the same class or different classes of the same teacher throughout the day.

c. During each session or while watching or listening to the tape, script the lesson to capture what is occurring.

d. After each data collection session, record narrative observations in field notes.

e. Using the CPR, count the number of HOT questions and comments made by the teacher and the students; count the number of knowledge/comprehension questions and comments made.

2. Step Two: Develop and Implement an Improvement Plan
a. Analyze the data from Step One.
b. Set goals for improvement.
c. Investigate possible strategies.

\section{Step Three: Reassess}

a. Collect new data as in Step One above.

b. Calculate the results. Use a chi-square analysis.

\section{Step Four: Reflect and Develop Future Plans}

c. Provide a summary and conclusions.

d. State next steps.

Step One: Assess Numbers and Types of Questions Using the Classroom Practices Record. A sample of verbal interactions is recorded in Table 1. These represent an initial fifth-grade reading lesson about the book, Number the Stars, by Lois Lowry. The school Principal was the observer and an EdD candidate. Therefore, these data were collected for a course project rather than for a teaching evaluation. For this 
observation, students and the teacher asked $10(\mathrm{~K} / \mathrm{C})$ questions compared to four HOT questions. Specifically, teachers asked five K/C and three HOT questions, while students asked five $\mathrm{K} / \mathrm{C}$ questions and one HOT question.

Table 1:

Classroom Practices Record (CPR): An Example of Verbal Interactions

\begin{tabular}{|c|c|c|c|c|}
\hline \multicolumn{2}{|c|}{ WHO AND TO WHOM CODES: } & \multicolumn{2}{|c|}{ WHAT CODES: } & WAIT TIME: \\
\hline $\begin{array}{l}(\mathrm{T}) \\
(\mathrm{S \# 1}) \\
(\mathrm{S} \# 2) \\
(\mathrm{S}) \\
(\mathrm{AL})\end{array}$ & $\begin{array}{l}\text { Teaching adult } \\
\text { Target Student \#1 } \\
\text { Target Student \#2 } \\
\text { Any Student } \\
\text { Students at large }\end{array}$ & $\begin{array}{l}\text { (KC) } \\
\text { (HOTS) } \\
\text { (RC) } \\
\text { (R) }\end{array}$ & $\begin{array}{l}\text { Knowledge/ } \\
\text { comprehension question } \\
\text { Higher-order thinking } \\
\text { skills question } \\
\text { Request or command } \\
\text { Response }\end{array}$ & $\begin{array}{l}\checkmark \text { Minimum } \\
\text { wait time } \\
\text { (3 seconds) }\end{array}$ \\
\hline
\end{tabular}

\begin{tabular}{|c|c|c|c|c|}
\hline WHO & TO WHOM & WHAT & $\begin{array}{l}\text { WAIT } \\
\text { TIME }\end{array}$ & NOTES \\
\hline $\mathrm{T}$ & $\mathrm{AL}$ & $\mathrm{K} / \mathrm{C}$ & $\boldsymbol{V}$ & $\begin{array}{l}\text { "What do you think this chapter will be about } \\
\text { based on the title?" }\end{array}$ \\
\hline $\mathrm{S}$ & $\mathrm{T}$ & $\mathrm{R}$ & & "Maybe like when the Nazis came to the house." \\
\hline $\mathrm{T}$ & $\mathrm{AL}$ & $\mathrm{K} / \mathrm{C}$ & $\checkmark$ & $\begin{array}{l}\text { "What happened at the end of the chapter } 4 \text { to } \\
\text { support your answer?" }\end{array}$ \\
\hline $\mathrm{S}$ & $\mathrm{T}$ & $\mathrm{R}$ & & $\begin{array}{l}\text { "...the Nazis identified the 'dark haired girl' as } \\
\text { Ellen." }\end{array}$ \\
\hline $\mathrm{T}$ & $\mathrm{AL}$ & $\mathrm{K} / \mathrm{C}$ & $\boldsymbol{V}$ & $\begin{array}{l}\text { "Can someone please summarize what happened } \\
\text { in this part of the story?" }\end{array}$ \\
\hline $\mathrm{S}$ & $A L$ & $\mathrm{R}$ & & Examples given... \\
\hline $\mathrm{T}$ & $\mathrm{AL}$ & $\mathrm{K} / \mathrm{C}$ & $\checkmark$ & "How is Annemarie acting?" \\
\hline $\mathrm{S}$ & $\mathrm{T}$ & $\mathrm{R}$ & & "She's acting like it's another day." \\
\hline $\mathrm{S}$ & $\mathrm{AL}$ & $\mathrm{K} / \mathrm{C}$ & $\checkmark$ & $\begin{array}{l}\text { "If the Nazis come, will they figure out that Ellen is } \\
\text { a Jew?" }\end{array}$ \\
\hline $\mathrm{S}$ & $\mathrm{S}$ & $\mathrm{K} / \mathrm{C}$ & $\checkmark$ & "Why is Ellen acting like she is the dark queen?" \\
\hline $\mathrm{S}$ & $\mathrm{S}$ & $\mathrm{R}$ & & "Because she played this part in the play once." \\
\hline
\end{tabular}




\begin{tabular}{l|l|l|l|l} 
WHO & TO WHOM & WHAT & WAIT & NOTES \\
\hline T & S & HOTS & $\checkmark$ & "What type of person is Annemarie based on evi- \\
dence in the story?"
\end{tabular}

Step Two: Develop and Implement an Improvement Plan. Following the first observation, the principal shared his data with the classroom teacher. Despite preparing questions in advance and posing numerous HOT questions, this teacher was somewhat disappointed with the results. She wanted more student engagement and greater evidence of higher order thinking. The next aspect of the plan was to develop a way to achieve these goals. The observer and teacher discussed different types of questions based on Bloom's Taxonomy (Bloom, 1956) and decided that students needed training in how to identify and write different types of questions. 
The improvement plan had three distinct components: First, KC questions and HOT questions were reviewed with students; Second, students were asked to develop and recognize different types of questions; Third, students formulated their own questions, which were then both self-scored and scored by the teacher. The resulting information was used to develop a set of exemplars for question types. The guidelines for this strategy are listed in Table 2.

\section{Table 2:}

\section{Definitions and Examples of Questions}

\begin{tabular}{|c|c|c|c|}
\hline TYPE OF QUESTION & QUESTION E: & EXAMPLES & RUBRIC SCORE \\
\hline $\begin{array}{l}\text { Knowledge/ } \\
\text { Comprehension } \\
\text { (i.e., describe, } \\
\text { sequence, list, infer, } \\
\text { compare, contrast, } \\
\text { what, where, when, } \\
\text { how) }\end{array}$ & $\begin{array}{l}\text { Knowledge } \\
\text { - Who is the main } \\
\text { character? } \\
\text { - What do you think } \\
\text { the chapter will be } \\
\text { about based on the } \\
\text { title? } \\
\text { Where does the story } \\
\text { take place? }\end{array}$ & $\begin{array}{l}\text { Comprehension } \\
\text { - What was the prob- } \\
\text { lem in this book and } \\
\text { how was it solved? } \\
\text { - List five major events } \\
\text { in this story in } \\
\text { sequence } \\
\text { What was the } \\
\text { author's purpose for } \\
\text { writing this } \\
\text { story/chapter/book? }\end{array}$ & 1 point \\
\hline $\begin{array}{l}\text { HOTS } \\
\text { (Higher-order } \\
\text { thinking) } \\
\text { (i.e., evaluate, rate, } \\
\text { support, draw con- } \\
\text { clusions, why, } \\
\text { apply, analyze, criti- } \\
\text { cize, arrange, plan, } \\
\text { judge, select, evalu- } \\
\text { ate) }\end{array}$ & $\begin{array}{l}\text { - WOT Que } \\
\text { character) and (name o } \\
\text { - How is the problem in } \\
\text { to a problem you've rea } \\
\text { - Did the author do a go } \\
\text { setting believable? } \\
\text { - If you were in this situa } \\
\text { have done? } \\
\text { - Did the author make a } \\
\text { this story? }\end{array}$ & $\begin{array}{l}\text { estions } \\
\text { ship between (name a } \\
\text { of other character)? } \\
\text { this story comparable } \\
\text { ad before? } \\
\text { ood job in making the } \\
\text { lation, what would you } \\
\text { any mistakes in telling }\end{array}$ & 3 points \\
\hline
\end{tabular}


- Pretend you are one of the characters in the book. Write a diary about the happenings in your life for two consecutive days.

- Write a different ending to the book. Tell why you changed it.

- Find one word that describes a character in your book very well. Give five reasons for your choice of words.

- The climax of any book or story is the exciting or interesting part. Tell what you think is the climax of the book and why.

- Identify one problem in the book and give an alternate solution, one not given by the author.

- Whom do you think the author intended to read this book and why?

- If you could only save one character from the book in the event of a disaster, which one would it be and why?

- Which character in the book would you choose for a friend? Why?

Step Three: Reassess. The data collected during the initial and final observations can be placed into a chart to view any differences in the frequencies for asking questions (Table 3). 
Table 3:

Frequencies of Knowledge/Comprehension Questions and Higher Order Thinking Questions in a Grade Five Reading Class

TYPE OF QUESTION

\begin{tabular}{|c|c|c|}
\hline DATA COLLECTION PERIOD & $\mathrm{K} / \mathrm{C}$ & нОТ \\
\hline \multicolumn{3}{|l|}{ Pre } \\
\hline Teacher & 5 & 3 \\
\hline Student & 5 & 1 \\
\hline Total & 10 & 4 \\
\hline \multicolumn{3}{|l|}{ Post } \\
\hline Teacher & 0 & 4 \\
\hline Student & 3 & 9 \\
\hline Total & 3 & 13 \\
\hline
\end{tabular}

This information shows that there was a decrease in the number of $\mathrm{K} / \mathrm{C}$ questions and an increase in the number of HOT questions, but does not indicate if this difference is significant. A chi-square can be used to calculate statistical changes in frequency-level data. The data gathered prior to the program implementation can be considered the "expected" or pre values, if nothing changes and the number of questions obtained after the program implementation can be the "observed" or post values. To interpret a significant chi-square, a standardized residual $(R)$ is calculated for each of the categories as indicated in Table 4. Categories that have $R$ values of \pm 2 are "major contributors" (Hinkle, Wiersma, \& Jurs, 2003, p. 552) to a significant chisquare.

As a result of the fifth-grade classroom study, a final observation revealed that there was a significant change in the numbers and types of questions being asked in the classroom $\left(X^{2}=70.13, p<.05\right)$. Furthermore, the most important contributors to the significant chi-square were the facts that teachers asked fewer questions at the knowledge/comprehension level during the post observation as compared to the initial data collection period and students formulated a greater number of HOT questions after participating in the question recognition and writing activities. The latter follow-up information is indicated by the $\mathrm{R}$ values in Table 4, which meet or exceed the absolute value of 2 . 
Table 4:

A Comparison of Knowledge/Comprehension Questions and Higher Order Thinking Questions in a Grade Five Reading Class

\begin{tabular}{|c|c|c|c|c|c|c|c|}
\hline SUBJECT & $\begin{array}{l}\text { TYPE OF } \\
\text { QUESTION }\end{array}$ & \begin{tabular}{|l} 
PRE \\
(EXPECTED)
\end{tabular} & $\begin{array}{l}\text { POST } \\
\text { (OBSERVED) }\end{array}$ & O-E & | (O-E) ${ }^{2}$ & (O-E) $)^{2 / E}$ & $\mathbf{R}$ \\
\hline \multirow[t]{2}{*}{ Teacher } & $\mathrm{K} / \mathrm{C}$ & 5.00 & 0.00 & -5.00 & 25.00 & 5.00 & -2.24 \\
\hline & HOT & 3.00 & 4.00 & 1.00 & 1.00 & 0.33 & 0.58 \\
\hline \multirow[t]{2}{*}{ Student } & $\mathrm{K} / \mathrm{C}$ & 5.00 & 3.00 & -2.00 & 4.00 & 0.80 & -0.89 \\
\hline & НОT & 1.00 & 9.00 & 8.00 & 64.00 & 64.00 & 8.00 \\
\hline Chi-square & & & & & & 70.13 & \\
\hline
\end{tabular}

Step Four: Reflect and Develop Future Plans. These data support the argument that focused and explicit instruction can have a powerful impact on critical thinking skills. Additionally, teachers can benefit from having a colleague who serves as a "Critical Friend," providing feedback used for formative assessment. Focused mini-lessons provide students and teachers with opportunities to target specific areas of teaching in order to improve a "best practice." Clearly, this four-step process supports the notion that teachers can quickly and effectively improve practice through explicit instruction in the area of critical thinking, which can be part of a larger plan to improve student achievement.

\section{Additional Examples of Improving Questioning Skills}

Improvement plans. Using this four-step model, teachers have designed a variety of plans to improve the use of questions in their classrooms. Their efforts have usually been related to increasing the number of HOT questions asked by both themselves and their students. They have found that directly teaching students how to recognize and compose different types of questions has produced considerable changes in their ability and willingness to formulate questions of different types. These questions have been based on several different schemas, such as the six-category Bloom's taxonomy (1956) (knowledge, comprehension, application, analysis, synthesis, and evaluation) or the revised hierarchy (remembering, understanding, applying, analyzing, evaluating, creating) (Anderson \& Krathwohl, 2001). Other 
sequences related to cognition include questions related to recall, processing, and information generation (Landrum, 1990; Shrable \& Minnis, 1969), or questions related to declarative, procedural, and conditional information (Driscoll, 2005). Teachers certainly find it valuable to construct their questions as part of lesson preparation, and have found that when students are encouraged to write their questions in advance, they are better prepared to participate in classroom discussions.

Teachers have also developed specific plans to enforce a three-second waiting period between asking a question and calling on a specific student. They have used strategies such as tapping out the seconds, counting silently, or even placing a poster in the classroom to remind everyone of the value of pausing prior to expecting a response.

\section{Additional Results of Assessing Questioning}

Table 5 is an example where all $R$ values support a significant change in the total numbers and types of questions being asked in a grade two reading class $\left(\mathrm{X}^{2}=\right.$ $42.2, \mathrm{p}<.01)$. This teacher particularly focused on limiting the number of $\mathrm{K} / \mathrm{C}$ questions being asked and increased the number of HOT questions. She modeled HOT questions and required each student to produce at least one higher order question.

\section{Table 5:}

A Comparison of the Number of Knowledge/Comprehension and Higher Order Thinking Skills Questions by Teachers and Students in a Grade Two Reading Class

\begin{tabular}{|c|c|c|c|c|c|c|c|}
\hline SUBJECT & $\begin{array}{l}\text { TYPE OF } \\
\text { QUESTION }\end{array}$ & \begin{tabular}{|l} 
PRE \\
(EXPECTED)
\end{tabular} & $\begin{array}{l}\text { POST } \\
\text { (OBSERVED) }\end{array}$ & O-E & $(O-E)^{2}$ & $(\mathrm{O}-\mathrm{E})^{2} / \mathrm{E}$ & $R$ \\
\hline \multirow[t]{2}{*}{ Teacher } & $\mathrm{K} / \mathrm{C}$ & 25.00 & 3.00 & -22.00 & 484.00 & 19.40 & -4.40 \\
\hline & HOTS & 21.00 & 36.00 & 15.00 & 225.00 & 10.70 & 3.30 \\
\hline \multirow[t]{2}{*}{ Student } & $\mathrm{K} / \mathrm{C}$ & 22.00 & 8.00 & -14.00 & 196.00 & 8.90 & -3.00 \\
\hline & HOTS & 21.00 & 31.00 & 10.00 & 100.00 & 3.20 & 2.20 \\
\hline Chi-square & & & & & & 42.20 & \\
\hline
\end{tabular}


The chi-square statistic can also be used to analyze results across classrooms from different teachers. In a study of 11 science teachers, the frequencies of questions are averaged. There was a significant change in the mean number of questions asked $\left(X^{2}=89.69, p<.01\right)$. The greatest contributor to this result was the number of HOT questions asked by students (Refer to Table 6). Overall, teachers did reduce their total use of questions during a typical lesson by $17 \%$. In addition, the total use of HOT questions posed by students and teachers increased by $14.7 \%$. While this example shows that teacher use of HOT questions was not a major contributor to the significant chi-square, more class time and opportunities were established for students to pose better questions.

Table 6:

A Comparison of the Mean Number of Knowledge/Comprehension and Higher Order Thinking Skills Questions by Teachers and Students Across Eleven Science Classrooms

\begin{tabular}{|c|c|c|c|c|c|c|c|}
\hline SUBJECT & $\begin{array}{l}\text { TYPE OF } \\
\text { QUESTION }\end{array}$ & $\mid \begin{array}{l}\text { PRE: MEAN } \\
\text { QUESTIONS } \\
\text { ASKED } \\
\text { (EXPECTED) }\end{array}$ & $\mid \begin{array}{l}\text { PRE: MEAN } \\
\text { QUESTIONS } \\
\text { ASKED } \\
\text { (OBSERVED) }\end{array}$ & O-E & $(O-E)^{2}$ & (O-E) $2 / E$ & $R$ \\
\hline \multirow[t]{2}{*}{ Teacher } & $\mathrm{K} / \mathrm{C}$ & 7.00 & 6.64 & -0.36 & 0.13 & 0.02 & -0.14 \\
\hline & HOTS & 5.18 & 5.82 & 0.64 & 0.41 & 0.08 & 0.28 \\
\hline \multirow[t]{2}{*}{ Student } & $\mathrm{K} / \mathrm{C}$ & 5.36 & 6.63 & 1.27 & 1.6 & 0.30 & 0.55 \\
\hline & HOTS & 0.27 & 5.18 & 4.91 & 24.11 & 89.29 & 9.45 \\
\hline Chi-square & & & & & & 89.69 & \\
\hline
\end{tabular}

\section{Conclusions and Implications}

Teachers and students can increase their use of higher order questions in the classroom. Teachers who paid particular attention to the reactions of their students once an improvement plan was in place noticed that when some students began to model asking questions, more of them became involved in asking questions. One school principal not only observed the entire class, but also followed two students over time, and watched and recorded the increase in their participation. Another teacher observed that as a result of participating in the implementation plan, “ ... many students were interested in understanding their own cognitive 
processes, were aware of instructional preferences, and were able to monitor and assess personal levels of engagement during a learning activity" (B. Boller, personal communication, December 20, 2006). One important finding was that while the HOT questions increased on the part of students, the need for the teacher to explain and restate information in the lesson decreased.

These results indicate that over time, these teachers designed more opportunities for students to ask advanced questions. They added inquiry opportunities into their classes by creating inquiry-oriented activities and environments. Developing a plan to improve questioning skills is indeed a key variable in student involvement in inquiry (Shore, Aulls, \& Delcourt, 2007), resulting in a greater number of HOT questions being asked by both teachers and students. Through keeping the development of higher order questions at the forefront of teaching, critical thinking and inquiry strategies will be kept at the heart of educational improvement.

\section{References}

Anderson, L., \& Krathwohl, D. (Eds.). (2001). A taxonomy for learning, teaching, and assessing. New York: Pearson.

Aulls, M. W., \& Shore, B. M. (2007). Inquiry in education: the conceptual foundations for research as a curricular imperative. New York: Erlbaum.

Bloom, B. S. (1956) Taxonomy of educational objectives, handbook 1: Cognitive domain. New York: Longman, Inc.

Delcourt, M. A. B., \& Carkner, P. (1996, June). Teachers' and students' participation in an inquiry-oriented curriculum: The types of questions they ask and their perceptions of learning. Presentation at the Canadian Society for the Study of Education, St. Catherines, Ontario.

Driscoll, M. P. (2005). Psychology of learning and instruction. (3rd edition) Boston: Allyn \& Bacon.

Harris, R., \& Burke, K. (2008, September). Developing the essential features of inquiry. Science Scope, 40-46.
Hendrickson, S. (2006, January). Backward approach to inquiry. Science Scope, 30-33.

Hermann, R. S., \& Miranda, R.J.(2010). A template for open inquiry. The Science Teacher, November, 26-30.

Hinkle, D. E., Wiersma, W., \& Jurs, S. G. (2003). Applied statistics in the behavioral sciences. Boston: Houghton Mifflin.

Jansen, B. A. (2011, March/April). Inquiry unpacked: An introduction to inquirybased learning. Library Media Connection, 10-12.

Landrum, M. S. (1990). The effects of peer coaching as follow-up to inservice training on application of training to classroom practice. (Unpublished doctoral dissertation). The University of Virginia, Charlottesville.

National Research Council (NRC). (2000). Inquiry and the National Science Education Standards. Washington, DC: National Academy Press. 
Oliveira, A. W. (2010). Improving teacher questioning in science inquiry discussions through professional development. Journal of Research in Science Teaching, 47(4), 422-453.

Ramsey, I, Gabbard, C., Clawson, K., Lee, L., \& Henson, K. T. (1990). Questioning: An effective teaching method. The Clearinghouse, 63(9), 420-422.

Salon, C. (2008). Student Perceptions of Mathematical Self-Efficacy in the Context of the Instructional Setting and Problem Solving Activities (Unpublished doctoral dissertation). Western Connecticut State University, Danbury, CT.

Shore, B. M., Aulls, M.W., \& Delcourt, M. A. B. (Eds.). (2007). Inquiry in education: Overcoming barriers to successful implementation. New York: Erlbaum.

Shrable, K., \& Minnis, D.L. (1969). Cognitive levels analysis interaction model (CLAIM). In A. Simon \& G. Boyer (Eds.), Mirrors for behavior III: An anthology of observation instruments. Wyncote, PA: Communications Materials Center.
Starko, A. J. (2007). Teaching problem finding to elementary students: Views from the trenches. In B. M. Shore, M. W. Aulls, \& M. A. B. Delcourt (Eds.), Inquiry in education volume II: Overcoming barriers to successful implementation. Mahwah, NJ: Erlbaum.

Westberg, K. L., Archambault, Jr., Dobyns, S. M., \& Salvin, T. J. (1993). An observational study of instructional and curricular practices used with gifted and talented students in regular classrooms. Storrs, CT: The National Research Center on the Gifted and Talented.

Zembal-Saul, C., Blumenfeld, P.C., \& Krajcik, J. S. (2000). The influence of guided cycles of planning, teaching and reflection on prospective elementary teachers' content representations. Journal of Research in Science Teaching, 37(4), 318-339.

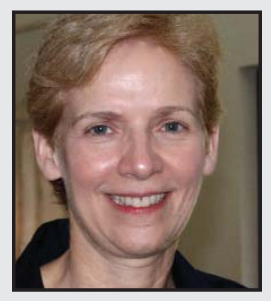

Marcia A. B. Delcourt is a Professor at Western Connecticut State University, Danbury, CT where she coordinates the Doctor of Education in Instructional Leadership Program. She has been active in education for over 20 years as a teacher, program coordinator, curriculum consultant, and researcher. She has also been a principal investigator or evaluator for over 25 state or federal grants. Her present research interests include assisting school personnel to design and refine techniques for identifying their gifted and talented children, developing inquiry skills in teachers and students, and encouraging teachers as researchers. She is presently working with educators and researchers through the government of India to identify and mentor children who have high ability in mathematics and science. 


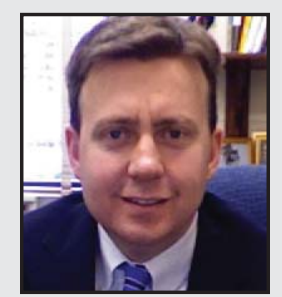

Jason McKinnon is Principal of the Branchville Elementary School in Ridgefield, CT. He has a Masters degree in education from Flinders University in Australia and is currently a doctoral candidate in Instructional Leadership at Western Connecticut State University. Earlier experience as a literacy specialist prompted Jason's interest in the importance of asking higher order thinking (HOT) questions to engage students in deeper learning. Jason learned that when students formulated HOT questions themselves, they interacted with their peers in a more meaningful way. His dissertation topic will explore HOT questions and the effects they have on students' critical thinking skills and reader self-efficacy. 